\title{
Buddhism, Christianity, Actuality
}

\author{
Kuang-Ming Wu \\ Rosebush University Professor of Philosophy, University of Wisconsin-Oshkosh, Oshkosh, USA \\ Email:kmwu2002@yahoo.com
}

How to cite this paper: $\mathrm{Wu}, \mathrm{K} .-\mathrm{M}$. (2017) Buddhism, Christianity, Actuality. Open Journal of Philosophy, 7, 168-185. https://doi.org/10.4236/ojpp.2017.72010

Received: March 1, 2017

Accepted: May 28, 2017

Published: May 31, 2017

Copyright (C) 2017 by author and Scientific Research Publishing Inc. This work is licensed under the Creative Commons Attribution International License (CC BY 4.0).

http://creativecommons.org/licenses/by/4.0/

\begin{abstract}
We here proceed in five steps, Buddhism in bits, Christianity in bits, their disasters, our disasters in existence, and then concrete actuality mysterious. Firstly, Buddhism takes things as mere collections of elements and thereby tries to convey the transcendent truth of Nirvana in this mundane-samsara world. Secondly, Christianity is based on ambiguous facts and elusive history, and is thereby undermined. Thirdly, Buddhist dissolution and Christianity in vain devastate their sheer existence. Fourthly, our own existence itself is devastated due to their disasters. Fifthly, such mess is caused by trying to definitely express the inexpressible but definite actuality. Still, both features of actuality-definite and inexpressible-tell of its monstrous objectivity (definite and indefinable) and monstrous subjectivity (lost and not-lost). All such twists show the fascinating time logic dancing alive in history. All this concludes with dreams caught by our viscera to resolve our monsters.
\end{abstract}

\section{Keywords}

Buddhism, Christianity, Actuality, Ambiguity, Collection

\section{General Observation}

We here proceed in five steps, Buddhism in bits, Christianity in bits, their disasters, our disasters in existence, and then concrete actuality mysterious. Firstly, Buddhism takes things as mere collections of elements and thereby tries to convey the transcendent truth of Nirvana in this mundane-samsara world. Secondly, Christianity is based on ambiguous facts and elusive history, and is thereby undermined.

Thirdly, Buddhist dissolution and Christianity in vain devastate their own existence. Fourthly, our own existence itself is devastated due to their existential devastations. Fifthly, such mess is caused by trying to definitely express actuality that is inexpressible but definitely concrete. Still, both features of actuality- definite and inexpressible-tell of its monstrous objectivity (definite and indefina- 
ble) and monstrous subjectivity (lost and not-lost). All such twists show the fascinating time logic dancing alive in history. All this concludes with dreams caught by our viscera to resolve our monsters.

All this shows time logic that pervades all entities. All things exist by undergoing itself through time, and existing itself is not haphazard but exhibits the logic of being itself as self-so in the tautology of existence, "It is what it is, and it will be how it will be" and understood as such by thinking. It is thus that all things exist as time logic ever concrete ever on the move. This time logic alive as existence is not usual logic that is out of touch with existence and never moves through time.

"What is time logic?" An important query you raised, my friend. Time logic is our viscera of life. Are you surprised? Let me explain. Things in life-family, friends, courage, piety, diary, knowledge, dinner, bed, you name it-sing music of themselves, and they cannot be summed up, surveyed, or analyzed into universals from outside in passionless indifference. Socrates famously tried it and famously failed. His failures are recorded in his early eristic dialogues.

All things concrete and actual are meant to be meticulously gone through to capture heartfelt. All things in life are typified by music that must be viscerally undergone through time to understand to enjoy, and thereby we can musically enjoy daily living in its own logic. Thus, our life is lived as time logic. Time logic is music singing joys of life. Time logic is life singing itself as it tastes itself.

As our living itself, this existential time-logic can never be violated without disasters. This essay tells of such disasters at the ultimate level of human existence, Buddhism and Christianity, which represent two extremities of no-being religion and being-religion. And so, this essay presents these two negative descriptions of time logic in Buddhism and in Christianity, and then, thirdly, their disasters. And then, this essay, fourth, presents an odd description of time logic in actuality in its monstrous objectivity and subjectivity. Now we are ready to walk these four steps.

Interestingly, our life is composed of the urgent and the essential. The urgent demands an immediate attention, and so we must use technical know-how to define and to manage to survive. The essential is often not even noticed. It is ambiguous and is quite difficult to figure out what it is, and so we tend often to bypass what is essential to live human. For all its non-emergency that tends to invite disdain from technical know-how, negligence of the essential consigns us to bestial inhumanity.

Religious scriptures in all their outmoded quaint dusts are precious and essential to us because they elucidate the essential in life and guide us to the Beyond. Of course there may be bad religions, whatever they may be, but somehow we instinctively avoid them for noble religions that we adore and aspire after. Buddhism and Christianity are cited below as two extremes-no-being religion and being-religion-to typify all religions that ennoble us. Both Buddhism and Christianity are yet surprisingly filled with disasters of their own.

One: Buddhism scattered into bits: 
Time logic is existential logic, unlike usual logic irrelevant to existence. Here is a terrible example of violation of existential time-logic, Buddhism. Its violation is detailed in three critical if not devastating points. One, Buddhism confuses levels of existence. Two, Buddhism confuses being-realm with no-being realm. Three, Taoism and the Bible are in the being-realm, and so they are not Buddhism.

One, Buddhism says there exists nothing because things are made of elements that are themselves nothing, and they will be nowhere anyway. All things are grass and flowers, and grass and flowers are here today, to vanish into nowhere tomorrow, nowhere to be found. All existence is no-existence, all in vain. Buddhism commits here a fatal confusion of levels of existence in space and in time, each in its own integrity never to be confused one into the other. But Buddhism sadly does so.

"All is atoms" does not say "Stones and trees are nothing, for they are atoms that do not exist, merely whirling around". Besides, "All will be nowhere" does not implicate "all is nowhere now". Existence has different levels that cannot be collapsed into one, and thereby to lump them into an all-out illusion. Can we say that the precious baby cooing irresistible now will eventually die anyway, and so we may as well bury this baby now? Would anyone dare say so? Such atrocious thought would instantly raise our angry eyebrows.

This instance tells us clearly that the confusion of levels in time (as well as in space) is absolutely invalid and unallowable. But incredibly Buddhism itself commits such a one-dimensional illusion, and tells us that we are in illusion. Such self-twisty one-dimensional declaration is all right-Chuang Tzu said 2/83, "I say you are dreaming, and saying so, I am dreaming, too"-if performed in a tongue-in-cheek self-consciousness. Sadly, Buddhism commits such self-contradictory illusion without itself knowing about it so illogical, invalid, and far contrary to our common sense.

This illegitimacy of confusion of levels cuts deeply and fatally into Buddhism itself. This fatality will soon reappear in the next point. Let us put it this way. In saying that all things are an illusion, Buddhism exists to say that there exists no existence. Buddhism here falls into the liar-paradox that says "I am a liar" who can neither be affirmed nor denied without denying the affirmation or affirming the denial.

Self-liar thereby destroys himself in self-contradictions on both affirmative side and denying side. In the same way, Buddhism exists to deny existence, to wit, it exists to deny its own existence. Thus Buddhism is denying itself while assuming its own affirmation of its existence without which its denial is impossible. Such self-affirming self-denial reenacts the liar-paradox that destroys itself as it destroys Buddhism.

Two, Buddha I am sure will respond, "You have totally missed my point, my pal. The precious Truth is 'Empty of empty, all is empty,' when 'all' is looked at in the perspective of the Beyond-all, from the Other Shore. In the Beyondhere-now, 'here' is nowhere and 'now' is not-now. My explanation of this Truth 
by skandha-elements-in aggregates is a mere upaya, which is a convenient and temporary expedient to convey this ultimate Truth beyond this samsara-mundane world.

Upaya the expedient is a handy stopgap raft to carry people over to the Other Shore beyond this shore of all things. Once people have reached over there, people will realize that there has been not a thing at all. There is not a raft, as they have reached nowhere, not anywhere, ever. In fact, not even they themselves have existed; they would now realize this no-realization. But even 'now here' is actually nowhere. This convenient raft of 'now here' is a raft to help us blow-off of all, and even this raft is blown off away, not existing. All this is a Nirvana, Bliss ineffable".

Hearing all this, I sigh my big deep sighs with Buddha, but now in my own way. What he says may well be true in the Nirvana-realm where there is nothing. Is this Truth itself a nothing? In any case, such strange truth is beyond us in our commonsense being-realm, whether this realm "really exists" also or not. Therefore, he must be in our usual common realm to tell us within our realm about such truth out of our realm. He must jump out of his Nirvana-realm to tell us of his Nirvana-truth, and yet the telling must be done inside our realm as we are within our realm. He must be in and out of our realm to tell at all of this Truth, whatever it is.

And so, we are puzzled to our core. Is his very "telling" inside the realm of Nirvana or outside Nirvana-realm? Even if we omit the further complication that Nirvana is not a realm, his telling of Nirvana must commit a confusion of realms, in-and-out of Nirvana, in no-realm and out of no-realm. Such confusion this time is embracing both no-realm and realm, and so the confusion now is more radical than the confusion above of realms within our common sense. He is now impossibly squeezed. Either he must be silent and not-tell at all, or else he must admit his confusion that abolishes his very telling. He can thus neither say nor not-say; he can neither not-tell us nor tell us.

How can he say the not-say, if he wants to say at all? Now, if he admits this radical confusion at all-would he, though?-where would his admission of radically confusing the realm with the no-realm lead him? His tongue is tied up, making it impossible to say anything at all or not say anything at all. Buddha is squeezed into that terrible liar's paradox again, this time neither self-destroyed nor not self-destroyed, perhaps worse than the self-liar's situation. After all, Buddha does not tell a lie!

When things are literally "inexpressible" this oddly "I'm a liar" way, not just nothing can be said, as things to be said kill one another. Here, nothing can exist to be said, as everything is so curled up negatively into itself. But then, isn't this odd "nothing" what Buddha wants to tell us of, after all? Is this the "precious Truth" he intends to convey us? Still, is this "nothing" the same as his Nirvana-nothing? Is this "nothing" his Truth that is Nirvana? He is in hot water now, twist and turn as he may. I heave my big huge sighs for him with him. Poor Buddha has no way out of his logical cul-de-sac he concocted for himself and 
falls into.

This tough squeezed situation is graphically illustrated in the Bodhisattva in “sad mercy 慈悲” for us all in our "illusory mundane world". He claims that his mercy for common folks urges him to make him to postpone entering Nirvana to stay in this samsara-mundane world to enlighten them on Nirvana. Deeply moved by his existential mercy, we are totally puzzled at his claim.

His claim is so illogical as to be unintelligible, and so it is impossible even to exist. Let me explain. Enlightenment gives knowledge but Nirvana abolishes knowledge. Enlightenment toward Nirvana gives knowledge to abolish knowledge, as even the "knowledge of Nirvana" is not possible. Bodhisattva tries to have the Nirvana-cake and eat it, both such nothing vain acts. Watching him closely, we realize this situation. An enormous difficulty, derived from existential incoherence of living in dying, is the Bodhisattva's daunting root of his impossibility to legitimize performing merciful acts of Bodhisattva.

Bodhisattva's sad mercy is matched by the sad butchery that went on until each side of the "enemies" were killed off by the other. The fact that such butchery was narrated as Story of the Heike significantly indicates that such killing-off is another vacuity, real as unreal. Sad violence is as vacuous as sad mercy. All is sound and fury, signifying nothing of nothing! Macbeth the tragic hero of the story by his name-just a story, signifying nothing!- was correct. This correct truth itself signifies nothing, to be expediently by-named "Nirvana".

In contrast, Christianity begins all loving acts at the loving God, so that all dilemmas of love-acts, whatever they are, are packed and pushed away into God up there, having nothing to do with our human love. Buddhism has no such convenient escape hatch to stay coherently sane as Christian love safely goes on, always pushing whatever incoherent-such as loving our hateful enemies-to Jesus on the cross that incarnates divine love that makes no sense. Sadly, Buddhism has no such convenient packing away.

Buddhists begin at "all beings as empty", thereby equalize every act into useless insignificance. Violence is here indifferently equivalent to love. Why then do we have to perform love acts at all? Buddhist emptiness sweeps away the rationale for "sad mercy". Mercy turns as indifferently insignificant as any other act of indifference, hatred, or straight violence. Such an impossible dilemma comes straightly from Buddha's own confusions of realms and of realm with no-realm.

Three, we now come to cleaning up things. We must take note of five sorts of negativities in this world of ours as not Buddhism, Taoism, ignorance, the Bible, Christian death to the self, and our mundane judgment that Buddhists are evil. All these five negativities seem similar to Buddhism but in fact irrelevant to Buddhism. First, Lao Tzu's (11) non-being 無 that rooms things does exist in being-realm to room existent things, as an empty hotel that we must pay to stay in. Lao Tzu's non-being 無 like this empty hotel has nothing to do with no-being 空 of Nirvana in Buddhism.

Secondly, Japan says, "Not-knowing makes a Buddha" out of a person immune from exploding at the unpleasant news. Such negative immunity from 
negative ignorance-that redounds into positive bliss-is totally in the being-realm, far away from Buddhist no-being. Ignorance in being-realm is bliss in being-realm. Ignorance in being-realm can be amply filled up with knowledge in being-realm, but Buddhist no-being can never be filled up with anything in the being-realm or no-thing in the no-being.

Thirdly, the saying "All is vanity" that begins Ecclesiastes in the Bible puffs air so insignificant so seemingly similar to Buddhism, as such puff is the sigh of insignificance. "Vanity" is "vapor or puff of wind, habel" (Seow, 1997). Still, this sigh is sighed "under the sun" of God who creates beings. This insignificance resides in being-realm under being-God who creates beings, not in Nirvana of no-being. "All is vanity" is not "All is vacuity".

Christian "vanity" is puffed out as a sigh of insignificance "under the sun" of being-Creator of beings; this puff basks in the sunshine of being. In contrast, Buddhist "vacuity" has no such puff, no such insignificance, and no such "sun". Vacuity here is a nothing of nothing, all a vacuous nothing. The self-forgotten “selfless ultimate person 至人無已” of Chuang Tzu affirms the true person in being-realm, and so this person is not “Nirvana no-self 涅槃空己” where no self exists.

Fourthly, by the same token, the Buddhists alive practice death. Being full and alive, they try to be empty in the no-being realm, and thereby fall into a terrible self-twisty cul-de-sac. In contrast, Jesus helps Christian believers to also die to their self, and then they come back alive due to Jesus. In their death-to-life drama these believers are not empty, due to their being-Jesus who is the creator of beings. Christians who accept Jesus do die to their self, but they in their very dying are fully in the being-realm, thanks to their being-Jesus their creator and re-creator.

Now, here is a fifth clean-up. Some people may say, "Buddhists are evil. They are of the devil". Three responses are in order. One, the Buddhists are not unethical, and so they are not evil. They never hate, tell a lie, attack, much less kill; on the contrary, they have pity on us common people. This is because they even claim that they themselves do not exist, and practice death while they are alive. How could a no-person alive be evil, then? In fact, we are daunted by such a no-person beyond good and evil, and still staying good! We could have behaved voluptuously, claiming to be beyond all good and evil!

Two, "They are of the devil" is precisely what the "good Jews" judged Jesus to be (John 8:48). Jesus tells us point-blank to begin Matthew 7, "Judge not". This is simply because with a big plank in our eye, we cannot judge a tiny speck in your eye. We the forgiven sinners who used to be of the devil must never judge "you" our fellow human beings to be of the devil. Those who live in a glass house must never pick a stone. Besides, how could no-unethical no-persons be of the devil? Buddha has gone through meeting "devils" and repulsed them with his own no-personhood. Such no-persons still remain compassionate, and such compassion is very difficult to oppose.

Three, the Buddhists are not evil or of the devil, but they are wrong in prac- 
ticing death while being alive. Their practice is so incoherent-trying to die while staying alive-as to be unable to exist as such. So, their being wrong is peculiar; they are so radically incoherent as to be unable to even exist as "they". This incoherence at the root of their existence is the only point deserving of attack, for "emptiness" in itself has nothing graspable.

Even attacking it this way remains quite hard, however, because they are good gentle persons and they are our fellow human beings. But in our fellow-love, we still ought to point to their incoherence; this combination of love of fellow beings with honest pointing to their wrong is our further difficult life-task. This task may be a part of loving enemies who remain our fellow human beings created by our commonly shared God.

"Do you mean to say that Buddhism is a fallacy?" Well, "fallacy" means that a claim exists as false and not-true. Instead, I mean in the above to say that Buddhism is so incoherent (as "I'm a liar" is) that it cannot even hold itself together coherently to exist as Buddhism. I have exposed Buddhism itself as incoherent, if the above argument on realm-confusions is valid. Incoherence is inherent in our ultimate aspirations in religions.

Two: Christianity scattered into bits:

Interestingly, the Buddhist has the pain of radical confusion of being-realm with no-being realm in conveyance of the Nirvana-truth from one realm to another that "does not exist"; the conveyance itself typifies the troublesome "relation" between being-realm and no-being realm in Buddhism. Can you imagine how the very conveyance of Buddhist Nirvana-Truth involves the Truth itself, so much so that the difficulty is itself the Truth? Ouch! How could the Truth be the difficulty?

But such pain not only does not exist in Christianity. Christianity positively revels in the confusion of this world and the Beyond. Such joy of confusion is called the Incarnation of the transcendent Love into its created world down here among us; the joy is even described as a homecoming of Creator God in his created world. And then, incredibly, this Christian joy of the factual historicity of the Incarnation breeds in turn its peculiar headaches-one on fact, another on history, both hinged on myth, and they are all correlated with "concrete" and "actual".

Since Christianity as the Incarnation focuses on fact incarnated, we must consider. We note two points both unexpected that divides Christianity into devastating bits. One, "fact" is a time-notion; fact slips no-fact myth as time goes. Two, still Christianity requires "fact" to be solidly fact, never shifting into mere myth. These two points compose Christianity, and each point goes contrary to the other, to tear up Christianity.

To begin, first, contrary to our usual expectation, fact itself slips into a no-fact myth in time. The three-tiered cosmos was an undisputed fact in old days. Such "three tiers" are now a no-fact myth. Bultmann's demythologization project proposes to get rid of such old-day myths to get at the eternal kernel of Christian facts unchanging. The project sounds sound and sensitive enough. 
We must sadly say, however, that Bultmann is obsessed with "fact today" as unchanging. Such is the fact-superstition that both supports his project to rid of myths yesterdays as seen today, and destroys his project, for his fact-superstition tells of the same project tomorrow that would "safely" get rid of his project today. His project oddly enacts the "I am a liar" paradox to destroy itself. So we think and judge him.

But then, secondly, Bultmann's $>$ project stubbornly refuses to go away, for taking it away takes away the very Christianity itself that requires such "fact-superstition" as its bedrock to stand on as the solid Incarnation of God's Son, humanized into fact that must be unchanging. Changing this Jesus-fact changes away Christianity. Firmly establishing Christianity depends on Bultmann's factsuperstition. Now point-one that denies Bultmann and point-two that requires Bultmann mutually conflict to tear up Christianity. Christianity is divided, and a house divided against itself cannot stand. Such a sad story of Christianity we are now to rehearse.

In order to elucidate such peculiarly Christian headaches, we must go to an odd area. "Now, let me bring us back to the basics. Is the concrete the same as the actual?" A good point you raised, pal. Actual and concrete are distinct but inseparable. For example, myths are actual but not concrete, waiting to turn concrete by us myth-makers and executers. We are the hinge of the concrete and the actual.

Myths are actually dreamed up and planned on by us. Actual myths are what pull us ahead into mythical "better tomorrows". And yet, our actual dreams of myths are just that, a puff of dreams in stacks of papers and cards. These myths require us, in fact urge us, to make them concrete. Our dreams of myths are actual and not (yet) concrete, on their way to becoming concrete through our struggles to concretize these actual myths.

Besides myths, another aspect of the concrete is "fact", this time distinct and inseparable in time in a reverse way. We usually take the concrete as solidly factual, unaware that facts are born in time, and then die in time into ancient legends of "myths" well-nigh unintelligible now. For example, the Bible is an old collection of old stories of "facts", many of which are now impossible even to understand. 1 Kings 13, to cite a random example, is such a collection of many such facts-turned-myths.

We take myth to be actual dream of the future on its way to being concretized. And then, fact comes in to turn itself into myth; myth now means past not-actual, no longer concrete now. "Is fact actual or concrete?" Good point you raised, pal. Fact grows dead into past myth. Myth here is now not actually real but just an illusion. So, fact is concrete and actual. Such fact, however, is timely, to grow dead into past-myth.

And so, history now passed away is all myths that are neither concrete nor actual. History is all past-myths. Take away myths, and history vanishes. No wonder, by advising us that questing historical Jesus is in vain, Schweitzer tells Bultmann that his demythologization simply destroys the entire Christianity that 
is based on history, though this history must still be actual and concrete "here now" to support our faith. This is a logical telling, not actual telling.

Such twisty "history" - both all past-as-myths not existent and all concrete and actual "here now"-tells that history is impossible to exist, neither as existing here now nor as not-existing, nowhere here now. Such twisty "history" destroys Christianity, as we will see soon. So, Schweitzer wants us to stop questing for historical Jesus, and he then lands into another trouble. Thus, I may have clarified the situation, but at the same time I have revealed its complexity. My point is that this complexity spells the disastrous downfall of Christianity.

In any case, Schweitzer in this way demythologized Bultmann himself who is in quest of solid factual Christianity. After both men, nothing is left in the Christian Incarnation into history, except our myth-as-dream called "faith". Our faith may be concretely performed, but our faith does not actually exist anymore. All things Christian float in a vacuum. Concrete Christianity of ours exists nowhere as actual. This sad story must now be rehearsed.

Bultmann's now familiar project of demythologization proposes to take away the outmoded stuff in the Bible (Bartsch, 1953), such as three-tier cosmos made of heaven above, earth below, and hell underneath, so that we today can get at the eternal Christian message consisting of solid facts based on today's solid ideas of what true fact consists in, the ideas such as Heidegger's existentialism, for example.

Bultmann's operation is made possible by naively assuming that the "world of facts today" is solidly factual forever, while ancient world is made of myths, not fact. This assumption shows Bultmann imprisoned in today's European myths. More seriously, his demythologization expresses facts-minus-time that amounts to "fact"-superstition, and any superstition prevents sensible understanding.

Such fact-superstition is fact as time-alive stripped off its time-aspect that makes fact alive. Fact-superstition kills facts coming alive and then growing naturally into myths now not-existing. Fact-superstition kills the growing life of facts. This fact-killing by imprisonment-today and by stripping fact off of its time-aspect sounds incredible and so it needs some explanation if not demonstration.

Such superstition is one aspect of belief-in-science that takes science to pursue "facts" as eternal and unchanging. Such belief in fact-as-such as eternal fills all world history of knowledge. Newton's "absolute space-and-time" is one factsuperstition to which Kant fully subscribed unawares, whose Critique of Pure Reason uncritically elaborates naively this fact-superstition; Kant was totally unaware that his Critique was itself an expression of a huge uncritical fact-superstition.

Fact-minus-time tells of death of facts-in-time that is jumping alive to then quietly grow away into myths that is no-fact. Einstein relativized Newton. Einstein's "relativity" amounts to recognizing facts as part and parcel of time logic, whose art is history. History is the art of reenacted grasp of facts now passed on into no-fact myths. History reenacts myths-now into facts now. History is the art 
of timed facts in time logic, as facts express time logic passing on. At least so we would think. We would be surprised to realize-as we would see soon later-that the situation is much more complex than such cavalier shoveling aside of "facts".

Another supposedly sensible warning is Schweitzer's well-known warning that our "quest of historical Jesus" is hurtful and impossible, and our faith in historical Jesus is based on our faith in Jesus, not on knowing "Jesus after the flesh". So we have Bultmann's demythologization project and Schweitzer's warning against our quest of historical Jesus. Are we blessed with these two enlightened wise counsels? On the contrary, these counsels show how we have huge problems that we have landed long time ago, totally unawares.

Now, we have just finished those devastating self-involved contradictions in both Buddhism and Christianity. We now must proceed to describe such self-contradictions as disasters in both religions that redound to our own disastrous devastation to our very existence itself, and then go on to rely on the inexpressible nature "actuality" to resolve all disasters, logical and existential, both in religions and in ourselves.

Three: Disasters in religions:

Few people realize that these two proposals pose quite a deathly threat to the Christian faith and worse, for they spill beyond disasters in Christianity into our very living. We can now scarcely live on. Both proposals goes on cutting very deep, as going-on is time in its logic on the move. Let me explain these terrible disasters, beginning at Bultmann and then go on to Schweitzer. Both are related disastrously.

Surprisingly, we are unaware that Bultmann's project is stubbornly needed today by Christianity and by our very living. Let us begin at Christian disasters. Without demythologizing no-fact myths, we cannot get hold of solid facts on which to base our faith in the factual Incarnation of divine Love. But if "fact" is a time-notion that would turn into no-fact myth later, whose "facts" are Jesus' acts? Are the solid facts of Jesus healing in Jesus' days just no-fact myths among us today? Bultmann come to help us demythologize fact-turned-myth to turn myth back to fact. But how would Bultmann even be able to demythologize our myths-today of all acts of Jesus and all no-fact myths of the ancient Bible? Christianity is all shaken apart into pieces.

The same disastrous dilemma faces Schweitzer's warning against "quest of historical Jesus" (Cicovacki, 2009; Joy, 1956). He mentions no reasons why "knowing Jesus after the flesh" is wrong and detrimental to our faith. Many historical biographies have been written on many sages to inspire and enlighten us through history. Why can we not write on historical Jesus? We have to go our way to consider what effects our quest of historical Jesus would have on us, without probing details of how historical quest is impossible.

Its impossibility has been indicated in our two critiques of Bultmann, to wit, historical quest imprisons us in our today, and assumes fact as eternal. The first woe results in fixation in us-today to dogmatically edit our "history of Jesus". 
The second woe results in fixation in the first century Jesus who spoke Aramaic of his time, to idolize that particular "historical Jesus". Such idolization robs Jesus of his free flexuous relevance alive to humanity in different ages. Actual historicity of a person is definite but inexpressible (to be detailed in "Five: Actuality"). Quest of a person in specific expressions goes nowhere.

But then, we are in for troubles. If it is impossible to find the historicity of Jesus on which our faith is based, on what is our faith based? Liberal theologians similarly warn us that secular standard historical research can never find the historicity of Jesus, as Jesus belongs to "sacred history". Conservative theologians on their part blissfully use our secular historical research to study and even prove that the facts of Jesus are solid facts. But then, these conservative theologians are unable to explain the "miraculous facts" (What a contradiction they are! Miracle violates factual sequence!) that fill the whole Bible. Tough luck on them as well! Now we have a dilemma. Is this "sacred history" the same as secular history? If so, our secular historical research should be able to find Jesus as historical. But is this "sacred history" different from secular history? If different, then Jesus is not historical as we understand history to be. Christianity crumbles on "history" that is its rock-basis but now turned impossible.

And we need not rehearse here again what we have lamented on the disastrous confusion in Buddhism of levels of existence in time and space, and even more disastrous confusion of samsara world in being-level with Nirvana ultimate in no-being level. Both sorts of confusions helplessly rendered Buddhism immovable, or rather, even impossible to exist as "Buddhism". Buddhism is hopelessly doomed; it cannot even state its precious Truth of all-as-nothing behind all-nothings.

Four: Our disasters:

Now, we consider next our disasters in existence. Surprisingly, the above cut-downs of Buddhism and Christianity cut down all our own activities today into impossible disasters. Let us consider Buddhism first. We recall how Buddhism has two routes to approach us, expediency and Nirvana the Beyond, and Buddhism thereby devastates our own existence in two ways. One, the expedient of fallacious "person as a collection of her parts" misleads us into taking our self as a mere nothing that is not Nirvana-vacuity. Two, the all-important Nirvana remains not logically-capable of being conveyed, and so we remain all lost in our samsara-mundane world.

Now let us consider Christianity. The Christian disaster on our existence is no less fatally serious. Are our activities solid facts? If so, these facts will never turn into no-fact myths. But if all facts today will turn into no-fact myths tomorrow, then we are actually dream-walking to dream-do all things. We are both factual and not-factual, and historical and unhistorical. Ouch! Time logic does such an ugly existential trick on us to devastate us; after all, we all live time logic. Now we can neither accept nor reject Bultmann or Schweitzer without destroying them and devastating us. Do all these disasters amount to reenacting the liar-paradox of "I am a liar" paradoxically? 
Now I cannot even breathe, for my breathing may be a solid fact and may also be a solid no-fact. No one can live in such self-curled self-stab of "may be"s. This terrible life-dilemma tells of time logic as brutally open and coherent. Time logic is coherent in a strange sense that it can be told, in this story-thinking way, as "incoherent". Of course it is little comfort to see time logic as open coherent in this way, for disasters remain disastrously to devastate both these religions and our existence. I see no way out of this horrendous dilemma in time logic and of time logic.

Five: Actuality monstrous:

And so, we are in terrible disasters now. After devastating Buddhism and Christianity, we ourselves are devastated to the core of our very existence. We cannot even breathe, when a still small voice of actuality suddenly comes and softly whispers in my ears. "Wait a minute, pal. Of course, you are frustrated, for you have been fighting against actuality that cannot be mocked. You are trying in vain to express actuality that is in-expressible though definite. Actuality is definitely actual but inexpressibly concrete and can never be captured definitively. What confronts you as really real is definitely concrete and actually inexpressible.

Take a person, for example. The person is somehow more than all her parts that compose her. These parts can be explained, and yet this "somehow more" cannot be explained definitively. Kant's punctuality or Beethoven's irascible temper can be explained but neither is Kant-as-such or Beethoven-as-such. Confucius' private strictures on his wife can be explained with historical documentation, but these details are not quite Confucius himself who is somehow more than they, as he as he remains elusive.

Again, Socrates' bisexuality and Pascal's stomach cancer can be explained explicitly in their biographies, but they are not quite Socrates or Pascal who are far beyond such definite explanations. Socrates and Pascal elude their definite biographies. They elude even their detailed personal memoirs all so precious, if historical research happens to find them. Socrates and Pascal remain beyond all what they left us, however detailed and comprehensive.

Such private peculiarities can neither be deleted nor be preserved. Of course we can say these private peculiarities, though explainable, do not quite represent the true person, but if we take them away, what is left of the person? Therefore, the person is both definite (explainable) and inexpressible (unexplainable). The person typifies all things concrete such as "fact" and history", all definite and yet inexpressible so elusive. This inexpressible aspect of actuality may be part of the reason why the quest of historical Jesus is forbidden as illicit and impossible.

Let me repeat this important point in a different light. We cannot express ' $I$ ' or 'you' that, or rather who, is not a definable collection of their facts or histories, much less of physical elements, however clearly explainable they are. Buddhism is wrong in affirming a person as just such a collection and no more. A person is much more than being definable this way, as she is much more subtle then visible or explainable. A person is inexpressible and indefinable though her 
parents would know her from inside, but still cannot express their intimate knowledge of her.

But "indefinable" here does not mean "indefinite" at all. I am definitely I myself as you are you, and, being each person as definitely each, we mutually differ in a no less definite way. A person is thus definite and indefinable. All this sounds complex but actually actuality is concrete and simple, and such simplicity is much subtler than logically definable. The simple concrete is definite and inexpressible. Simplicity here is subtle, not complex.

Disastrous collection-fallacy of Buddhist expediency and its failure to convey Nirvana-truth beyond this world in this world come from Buddhism trying to definitively express the inexpressible actuality, lured by its other aspect of being definite. Likewise, Bultmann and Schweitzer try clumsily to definitely express their points on actuality that is factual and historical. Actuality is inexpressibly concrete though quite definitely actual, not amorphous at all.

Your dilemmas of "fact and no-fact, historical and no-history" point to the indefinable side of a person all concrete. Your dilemmas thus expose Buddhism as wrong. What you have missed, though, is on the other side of the definite, trying also to definitely express the other indefinable side of the person. The person is both indefinable and definite, and neither side can be infringed on by the other side.

Let me repeat. The person cannot be defined by "fact" or "history" that is definable, for the person is definite in an indefinable way. "Indefinable" here is not mysterious but quite concrete. The sheer presence of the concrete confronts you as the concrete "I" and concrete "you" who are definite and indefinable. Actuality confronts you with these double aspects together that seem incoherent but quite actual".

Now, this actuality-whisper soothes away my sorrows of dilemmas on "fact" and on "history". Bultmann stubbornly pursues factuality, and Schweitzer no less clumsily warns us against straight quest of historical Jesus. What both men do amounts to this. They identically aspire after the definite concrete by way of definite-expression, as I also used to do to frustrate myself, to end up being trapped in a dilemma of "both factual and not-factual, both historical and unhistorical". I am now silenced and satisfied as I now realize all this subtlety of simple actuality as definite and indefinable.

Previously I have accused Buddhism of confusing levels and realms to end up being unable to explain and even exist as Buddhism. Now I realize that my accusation is legitimate only from the perspective of definite explanation. Actually, Buddhist confusion is a "confusion", to wit, Buddhism is all over all levels and realms. Buddhism is justified in being all over, for to it all things are vacuous, and vacuum implicates free floating all over.

And being all over cannot be definitely defined or explained, as definition and explanation work only within a definite area, and "all over" overflows all definite areas and realms. Buddhist conveyance in all its mess so self-contradictory precisely shows the inexpressible aspect of Buddhist Nirvana, as the inexpressible is 
as negative as Nirvana. It is thus that Buddhism is all self-consistent, after all.

The wish-washy features of fact and history I pointed up previously are also indicative of the inexpressible side of fact and history. Christianity is actually based on solidly factual history after all, yet as inexpressible in a definite manner. A spin-off out of this is paradox. This is because the inexpressible shares with the paradoxical a feature of being incapable of definite and straight explanation. One stunning example in Christianity of inexpressible paradox is 1 John 4:12.

This verse says that the perfect love of God is perfected by our imperfect mutual loving. This verse tells us that love however perfect is still perfected by its beloved. This is so incredible, but do we not remember Abraham pleading with God for the Sodomites, as Moses pleading with God for the Israelites? And God did listen to Abraham and to Moses, each time each one did. So loving God would listen to us pleading for our loved ones, each time we do in our love of them.

Our Parental Lover loves us, simply loving such pleading of our love! His delight satisfies and fulfills his Love, to thereby "perfect" his love, indeed. This is the precious message on love so perfect yet still being perfected by our imperfect love, in 1 John 4:12. And so, we say this: if so, love is so pleased when it is depended on. Love depends on being depended on! And so, love is frustrated when its pleading struggles are casually brushed aside. Love suffers long in being ignored. And so, perfect love eagerly helps us to inter-love, and thus the perfect love is perfected by our feeble imperfect inter-love. It is love that explains such incredulity of perfection being perfected by imperfection. In love and because of love, perfection is perfected by imperfection that depends on perfection. I have a strange hunch that this stunning verse 1 John 4:12 describes the reason why loving God reverses our pursuits of Moloch and of cannibalistic victim, by offering us his only Son and set us his Eucharist to eat and drink him. But I do not know how this verse legitimizes his reversals. Is it divine love so eager to help us to inter-love? Love stares at us in the face to embrace us as music embraces right here now, no ifs no buts. And yet, such blunt simple presence seeping inside us defeats all our straight explanation, being so subtle so complex beyond all logic, for, after all, how could perfection be perfected by imperfection, even in "love that depends on its beloved however imperfect"? Raymond E. Brown embraces this illogic of perfect love made perfect in imperfect love, in his The Epistles of John, The Anchor Bible, p. 521, cf. 256-257. But he did not squarely face up to this paradox.

Such is the paradoxical depth of God's perfect love depending on our dependence all too imperfect. It is a fact that love is in need of being reciprocated by love; such is a fact that is definite beyond dispute, and yet all this twist and turn of love specified in the above is inexpressible in straight definite expression, and so, love is inexpressibly definite. And we must keep this further point firmly in mind. Perfect divine love is made perfect in us. This "in us" is nothing less than stunning and stupendous. 1 John 4:12 says "in us" twice.

Love is not just a matter in Heaven. Love is the precious affair of hea- 
ven-on-earth in us. Love is the Incarnation of the sweetest symbiosis that is all-synergy through and through, for living is joy and so living together in love is joy all over, the sweetest of all in us in heaven and on earth. This fabulous love-symbiosis is accomplished by us in us among our family members who are our fellow human beings.

Still, surprisingly but actually, our intimate family members can be, and often turn out to be, our enemies who can and often do kill us. Loving enemies to death-even on the painful cross-perfects sweet love symbiotic. Such is the sweetest love serious that is not pretty. Such is the awesome truth of perfect love made perfect in its beloved, who is not at all perfect but quite often quite atrocious and deadly.

Heinous Sodomites, Herod, Nero, and Hitler-are they not our "family members" of fellow human being? - were destroyed in the end, now nowhere to be seen, history tells us. Meanwhile, Jeremiah (1:5) was known and chosen before birth, but, for all this, God of Love never proclaimed that those people bad and atrocious were created to be destined to be destroyed. Jesus even told Judas, "Go do what you want" (John 13:27).

In this surprising way, the sweetest love is quite powerfully serious. And yet this sweet powerful love is not pretty at all, for love embraces even death and hell not pretty as described above, and turns deadly both into servants of love of living, to let even enemies of killing live into no-enemy no-killing. The deadly enemies are now not our enemies but smiling friends of life, as they are now back to being our original intimate family members to live with.

Such is perfect love made perfect in us who are so imperfect. Love is thus the supreme affair of heaven-on-earth among us in us. Love is in the heaven so sweet and perfect, and this heavenly love is constantly living on earth, and we are its sweet part through our ugly enmity so deadly. Such is the absolute perfection of love through our ugly imperfections. All this is so great and so mysteriously indefinable as to bring me down to my knees.

But sadly the whole situation still remains indefinable and inexpressible; we stay hanging in midair, as we do not know how to deal with things concrete yet entirely inexpressible. How could anything so concrete be so inexpressible? We would have thought that if anything is brutally concrete, it should be graspable all-definitively. And yet, this raw presence of the concrete confronts us just as it is, as concrete and so simple! We are aghast at simplicity, all seen-through and stubbornly to defeat all explanations! Concrete simplicity is definite and inexpressible. So, I am silenced, now both silently satisfied and silently perplexed. "How are you perplexed?"

Just think! The simple concrete that confronts us so definitely is yet without expression in itself, and we cannot express it! The concrete confronts us in the face and we are at a loss, now lost and not-lost! We are lost, being incapable of expressing such simple concrete presence, and yet all this while we are not-lost, for no one is lost in the sheer concrete, as we are embraced as concrete concretely. We are now monsters, being lost and not-lost at once! 
It is thus that we ourselves are turned into monsters-lost not lost-before the monster-concrete in its sheer presence as "definite and indefinable", for-we are still puzzled-how could what is definite be incapable of being defined? This monster twofold may be what is pointed at by Buddhist Nirvana and Christian Incarnation. Buddhism and Christianity are redeemed by the monster the concrete actual that makes us monsters lost and not-lost.

And now, this whole strange bit must be clinched by this observation that is no less odd. We see that time is moving onward here. All these twists and turns in reasoning move on through attacking Buddhism, then attacking Christianity, and then devastating our very existence by our attacks, and all this finally landing us in actuality as both definite and indefinable so monstrous, to turn us ourselves into monsters lost and not-lost. All these unexpected twists and turns are the route that shows time logic monster-alive, as it moves unceasingly, all factually and all historically. These turns proceed actually and concretely, after all. This showing thus expresses inexpressibly the strange time logic so monstrous. Time logic is an actual monster concrete, indeed. Ha!

On the whole, looking back, we see that the situation still remains in a mess, of course. Still, for all this confusing mess so monstrous threefold, actuality, we ourselves, and time logic, now that we have gone through such twisty route ourselves, we feel that the atmosphere has somehow shifted. The monstrous storm has now shown soft sunshine with shy rainbows.

Previously, devastations in existential contradictions of Buddhism and Christianity-and all religions lying between these two extremes-have over-flooded into our devastations in existence. Devastations are no fun. We were deluged in miseries under disasters. Now, thanks to actuality whispering into our visceral ears, we can afford to get lost and remain not-lost, our pain of lost yet not-lost has changed into affordable repose in this pain, and the pain itself ceases to exist.

We can now afford to sing the music of elusive actuality that we definitely are, yet all remaining inexpressible. We now dance the painful mess that is turned our music of life itself. Monster for monster, we the monsters chant monstrously with the monster of actuality itself. Music is music of joy, even singing the mess the monstrous pain all over. Remaining a monster, time logic is music. Time logic shows itself as the musical monster indeed.

We have proceeded in five steps, Buddhism in bits, Christianity in bits, their disasters, our disasters in existence, and then concrete actuality mysterious. One, Buddhism takes things as mere collections of elements and thereby tries to convey the transcendent truth of Nirvana in this mundane-samsara world. Two, Christianity is based on ambiguous facts and elusive history, and is thereby undermined.

Three, Buddhist dissolution and Christianity in vain devastate their own existence. Four, our own existence itself is devastated due to their existential devastations. Five, such mess is caused by trying to definitely express actuality that is inexpressible but definitely concrete. Still, both features of actuality-definite and inexpressible-tell of its monstrous objectivity (definite and indefinable) 
and monstrous subjectivity (lost and not-lost). All such twists show the fascinating time logic dancing alive in history.

Now, here is a horrendous case of actuality definite and indefinable. My atheist friend snickers as I pray to our all-powerful God, in the belief that my feeble mumbles are heard by my all-powerful Father-God, as all fathers listen to their kids. When my God the Father listens, things happen. My atheist friend smiles condescendingly, "If there is such a nice God, why do you have to pray at all? Just tell him to destroy all 'pain' that comes on your way". I then timidly produce four points.

One, I do not pray to take away my pain, for such petition requires a God-like map of the whole universe. I do not know what I am asking for, since I am not God. Two, it is stronger to ask for strength to overcome what comes than to ask to take all pain away. My threshold of endurance will then shrink and my pain will increase if my pain is removed as it comes. Three, many potential disasters are actually being taken away without my knowing them taken away. Four, many natural events are miracles against disasters. Baby Moses was ;pulled out of the Nile by his archenemy's daughter and returned to his mother with pay (Exodus 3: 1-10). It was both natural and miraculous.

My atheist friend smiles again. "Why then did not God give Hitler a tiny headache to stop his idea of wiping out all Jews? It would have been natural and miraculous, right?" I would now be silenced. After all, all-powerful Love creating and loving all-feeble human beings is itself awesomely monstrous, so senseless. Sudden eruption of brutal racism is also no less awesomely monstrous, also senseless.

When both monsters collide, we only tremble in their midst. I cringe at "all" in all-evil and all-love. I now tremble in terror. My atheist friend and I myself are now both horrified before such monstrous mystery, as we are engulfed in abysmal ignorance of horrendous actuality, which definitely confronts us all to terrify us, while yet it remains totally monstrous-indefinable.

And then, all out of the blue, the wise American Indians drop into us an invincible counter-monster. This is their undying legendary dream of "dream catcher". We are all human, all living dreams beyond here now, to continue to catch dreams erupting from our deep viscera. We cannot help but constantly plan to engage implementing plans that are our spontaneous dreams. Each day dawns anew with fresh dreams of new plans, to catch us for us to catch them. No moronic people and not even insane people are without dreams. Bereft of dreams, we simply die away. This is what we mean by being human beyond being bare animals.

To kill people, we just need to kill off their dreams. Nazism famously tried it on a whole race of people. Frankl stubbornly rebels against it, precisely by going through it. (Frankl, 1984) thus shows us that strengthening our dreams can be performed any time anywhere, even by going through the harrowing experience of having our dreams killed off. These dreams are absolutely virile absolutely invincible, because their protest underwent their killing and survived their own 
killing! These dreams are truly the literal phoenix rising out of their own ashes, each time it is burned alive.

When dreams have stubbornly protested against their killing, even by undergoing their killing, these dreams are invincible through their own deaths. Dreams are thus amazingly tough. Dreams are tougher than we expect and dream for. Dreams are absolutely strong ubiquitously essentially, and dreams are thereby indispensable to living. Dreams are forever smiling as they continue to beckon us ahead beyond here now. If being engulfed monstrous is human, then catching dreams is humanly divine.

\section{References}

Bartsch, H. W. (1953). Kerygma and Myth by Rudolf Bultmann \& Five Critics. New York, NY: Harper Torchbooks.

Cicovacki, P. (2009). Albert Schweitzer's Ethical Vision: A Sourcebook. New York, NY: Oxford University Press.

Frankl, V. E. (1984). Man's Search for Meaning: An Introduction to Logotherapy. New York, NY: Simon \& Schuster.

Joy, C. R. (1956). Albert Schweitzer: An Anthology. Boston, MA: Beacon Press.

Seow, C.-L. (1997). Ecclesiastes. The Anchor Bible, Doubleday. New Haven, CT: Yale University Publications.

\section{Submit or recommend next manuscript to SCIRP and we will provide best} service for you:

Accepting pre-submission inquiries through Email, Facebook, LinkedIn, Twitter, etc. A wide selection of journals (inclusive of 9 subjects, more than 200 journals) Providing 24-hour high-quality service User-friendly online submission system Fair and swift peer-review system Efficient typesetting and proofreading procedure Display of the result of downloads and visits, as well as the number of cited articles Maximum dissemination of your research work

Submit your manuscript at: http://papersubmission.scirp.org/

Or contact ojpp@scirp.org 